\begin{tabular}{cc|c}
\hline Tarım Bilimleri Dergisi & Journal of Agricultural Sciences \\
& $\begin{array}{c}\text { Dergi web sayfası: } \\
\text { www.agri.ankara.edu.tr/dergi }\end{array}$ & Journal homepage: \\
& www.agri.ankara.edu.tr/journal
\end{tabular}

\title{
Antalya İlinde Serada Domates Üretiminin Kâr Etkinliği Analizi
}

\author{
Burhan ÖZKAN ${ }^{\mathrm{a}}$, Selim Adem HATIRLI ${ }^{\mathrm{b}}$, Erdoğan ÖZTÜRK ${ }^{\mathrm{c}}$, Ali Rıza AKTAŞ ${ }^{\mathrm{d}}$ \\ ${ }^{a}$ Akdeniz Üniversitesi, Ziraat Fakültesi, Tarım Ekonomisi Bölümü, 07100, Antalya, TÜRKIYE \\ ${ }^{b}$ Süleyman Demirel Üniversitesi, İktisadi ve İdari Bilimler Fakültesi, İktisat Bölümü, 32260, Isparta, TÜRKIYYE \\ ${ }^{c}$ Süleyman Demirel Üniversitesi, İktisadi ve İdari Bilimler Fakültesi, Ekonometri Bölümü, 32260, Isparta, TÜRKIYE \\ ${ }^{d}$ Akdeniz Üniversitesi, Alanya İsletme Fakültesi, Ekonomi ve Finans Bölümü, 07400, Antalya, TÜRKIYYE
}

\section{ESER BILGİSi}

Araştırma Makalesi - Tarımsal Ekonomi

DOI: $10.1501 /$ Tarimbil 0000001154

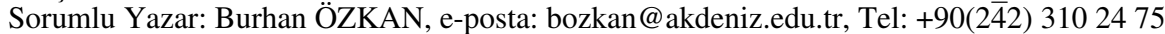

Geliş tarihi: 07 Ekim 2010, Düzeltmelerin gelişi: 24 Ocak 2011, Kabul: 26 Nisan 2011

\section{ÖZET}

$\mathrm{Bu}$ araştırmada, Antalya ilinde serada domates üretimi yapan işletmelerin kâr etkinliğinin belirlemesi amaçlanmıştır. Araştırma kapsamında, serada domates üretimi yapan işletmelerin sosyo-ekonomik özellikleri, üretimde kullanılan girdi miktarları, domates üretim faaliyetinin gelir düzeyi ile brüt ve net kâr seviyeleri de belirlenmiştir. Serada domates üretiminde etkinlik analizi için olasılıklı kâr sınırı modeli kullanılmıştır. Bu kapsamda güzlük, yazlık çift ekim ve kışlık üretim tek ekim dönemleri için stokastik translog kâr fonksiyonu ile etkinsizlik düzeyi tahmin edilmiștir. Ekonomik analiz sonuçlarına göre, tek ekim domates üretimi, çift ekim domates üretiminden daha kârlı olarak belirlenmiştir. Model tahmin sonuçlarına göre güzlük, yazlık ve kışlık üretim dönemleri itibariyle kâr etkinsizlik oranları sırasıyla $0.158,0.210$ ve 0.169 olarak hesaplanmıştır. Bu sonuçlara göre işletmeler arasında önemli seviyede teknik ve dağılım etkinsizlik farklılıkları bulunmaktadır.

Anahtar sözcükler: Stokastik kâr sınırı; Etkinlik; Kâr etkinsizliği; Sera

\section{Analysis of Profit Efficiency for Greenhouse Tomato Production in Antalya Province}

\section{ARTICLE INFO}

Research Article - Agricultural Economy

Corresponding author: Burhan ÖZKAN, e-mail: bozkan@akdeniz.edu.tr, Tel: +90(242) 3102475

Received: 07 October 2010, Received in revised form: 24 January 2011, Accepted: 26 April 2011

\begin{abstract}
The main objective of this research is to determine profit efficiency of greenhouse tomato farms in Antalya province. In the scope of this research, socio-economic characteristics of farms, physical input usage in the greenhouse tomato production, revenue levels and gross and net profits attained towards production activities were determined. In order to analyse efficiency of greenhouse tomato production a "stochastic profit frontier" model was used in the study. The level of inefficiency for fall, spring double crop and winter single crop production periods was estimated with the stochastic translog profit function. According to the economical analysis results, single crop tomato production was found more profitable than double crop tomato production. According to the model estimation results, the profit inefficiency rates for fall, spring and winter production periods were calculated as $0.158,0.210$ and 0.169 respectively. There are significant differences among greenhouse holdings in terms of technical and distributive efficiency.
\end{abstract}

Keywords: Stochastic profit frontier; Efficiency; Profit inefficency; Greenhouse 


\section{Giriş}

İşletmelerin tarımsal gelirinin artırılmasında önemli bir üretim faaliyeti olan seracilık ile ilgili, ilk uygulamalar Türkiye'de 1940'lı y1llarda Antalya ilinde başlamış ve 1970'li yıllardan itibaren plastik malzemenin kullanılmasıyla örtü altı üretim giderek yaygınlık kazanmıştır. Türkiye toplam örtü altı alanı 2006 yılı verilerine göre, 497 bin hektar olup bunun \%50'si Antalya ilindedir. İlin toplam tarım arazisi içinde örtï altı alanlarının payı \%4.07 olup, ildeki sebze üretiminin \%76.99'u örtü altında, $\% 23.01$ 'i ise aç1k alanda gerçekleşmektedir. Antalya ilinde toplam örtü altı alanı 225 bin dekardır. $\mathrm{Bu}$ alanın \%50.92'sini plastik, $\% 35.02$ 'sini cam ve \%12.16'sını ise plastik tünel olușturmaktadır (TKB 2006; TUIKK 2006). Üretim miktarı ve üretim alanı bakımından Antalya ilinde serada sebze üretiminde domates ilk sirada yer almaktadır. 2006 yılı değerlerine göre Antalya ili domates üretim miktarı ve alanı içinde örtü altı domatesin payı sirasıyla \%86.05 ve \%71.96'dır. Diğer yandan, Antalya ilinden gerçekleştirilen yaş meyve-sebze ihracat değerinin \%25'ini domates oluşturmaktadır (TKB 2005; TKB 2006).

Antalya ilinde serada domates üretiminin bölge ve ülkemiz ekonomisi için önemi nedeniyle işletme düzeyinde çeşitli yönleriyle incelenmesi oldukça önem taşımaktadır. Buna karşın serada domates üretiminin ekonomik yönünü inceleyen araştırma sayısı oldukça sınırlıdır (Özkan 2003; Özkan et al 2001). Söz konusu bu çalışmaların önemli bir bölümü de domates üretiminin ekonomik analizine yönelik olup etkinlik çalışmasına rastlanmamıştır. Dolayısıyla Antalya ilinde büyük öneme sahip olan domates yetiştiriciliği yapılan işletmelerde tek ürün ve çift ürün dönemlerine göre etkin bir şekilde faaliyette bulunup bulunmadığının saptanması, işletmelerin kârlılı̆ğ, uluslararası pazarlarda rekabet gücünün artırlabilmesi ve $\mathrm{AB}$ uyum sürecinde izlenebilecek politikalar bakımından büyük önem taşımaktadır.

$\mathrm{Bu}$ araştırmada serada domates üretimi yapan işletmelerde kâr etkinliği analizi ve işletmelerin sosyo-ekonomik özellikleri ile kâr etkinliği üzerinde etkili olan faktörlerin saptanması amaçlanmıştır.

\section{Materyal ve Yöntem}

\subsection{Materyal}

Araştırmanın ilk aşamasında araştırma alanı olarak belirlenen Antalya ili Merkez, Kumluca ve Serik ilçelerinde anket çalışmasının yürütüleceği köyler ile bu köylerde serada domates üretimi yapan üreticiler belirlenmiştir. Uygulanan anket aracılığıla üreticilerin genel üretim özellikleri, işletmenin demografik yapısı, işletmenin arazi varlığı ve arazinin kullanım şekli, toprak hazırlığı, sulama, ilaçlama ve gübreleme gibi teknik süreçler ve satı̧-pazarlama değerleri ile ilgili bilgilere ek olarak üreticinin domates üretim sürecinde karşılaştığ 1 sorunlar ile ilgili bilgiler de elde edinilmiştir. Araştırma anketi tek ekim ve çift ekim uygulaması yapan domates üreticilerinden farklı üretim dönemi için ayrı ayrı anket uygulanarak gerçekleştirilmiştir. Araştırmada güzlük dönem için 102 işletme, kışlık dönem için 85 işletme ve yazlık dönem için 69 işletme olmak üzere toplam 256 işletmeden elde edilen nitel ve nicel verilerden faydalanılmıştır. Birincil veri olarak anketler dikkate alınmıştır.

\subsection{Yöntem}

Antalya Tarım İl Müdürlüğü tarafından derlenen “Örtüaltı Kayıt Sistemi” kapsamındaki verilere göre işletmelerin sera alanları esas alınarak işletmeler üç tabakaya ayrılmıştır. Tabakalı Örnekleme ile Neyman Yöntemine göre örnek hacmi \% 95 güven aralığında ve ortalamadan $\% 5$ sapma ile 256 olarak hesaplanmıştır (Yamane 2001). Belirlenen ișletmenin araştırmanın yürütüleceği ilçelere göre dağılımı ise her ilçenin ilin toplam sera alanı içerisindeki sera payları dikkate alınarak yapılmıştır. Görüşme yapılacak işletmeci sayısının sera tiplerine (cam ve plastik) göre dağılımı yapılmıştır. Merkez ilçeden görüşme yapılan 121 işletmenin 58'i cam sera, 63'ü plastik sera; Serik ilçesindeki 71 işletmenin 23'ü cam sera, 48'i plastik sera ve Kumluca ilçesindeki 64 işletmenin 12'si cam sera ve 52 tanesi plastik seradan oluşmuştur. Araştırma kapsamında sera tipine bağlı olarak işletmelerin sera genişlik grupları; I. Grup; 2.99 dekardan küçük ișletmeler, II. Grup; 3.00-5.99 dekar arasında ve III. Grup ise 6 dekar ve üzeri sera genişliğine sahip işletmelerden oluşmuştur. Buna 
göre 256 işletmenin 117'si I. gruptan; 97'si II. gruptan ve 42 tanesi III. gruptan oluşmuştur.

Görüşme yapılan işletmelerde domates üretim faaliyeti ile ilgili fiziki girdi ve üretim değerinin belirlenmesinde tek ürün bütçe analizi yapılmıştır. Domates üretim maliyeti üretim sürecinde kullanılan fiziki girdi miktarları ve işletmecilerin ödemiş oldukları fiyatlar kullanılarak hesaplanmıştır. $\mathrm{Bu}$ hesaplamalar yapılırken Alternatif Maliyet Prensibi esas alınmıştır. Ekonomik analiz kısmında işletmelerin domates üretim değeri, domates üretim faaliyeti sonucu ortaya çıkan üretim masrafları, domates üretiminden elde edilen brüt ve net kâr değerleri sera tipi ve üretim dönemlerine göre incelenmiştir.

Teknik etkinliğin parametrik olarak saptanmasında, işletmenin ve işletme faaliyetlerinin özelliklerine bağlı olarak üretim, maliyet veya kâr fonksiyonları kullanılmaktadır. İşletmenin teknik etkinliğinin ölçülmesinde üretim fonksiyonu üzerinden olasılıklı sınır tahmini yapılması literatürde daha sık rastlanılan bir yaklaşımdır. Üretim fonksiyonları yaklaşımında işletmeler arasındaki girdi ve çıktı fiyatları ile işletmelerin sahip olduğu faktör bileşimlerinin aynı olduğu kabul edilir (Ali \& Flinn 1989). Kâr fonksiyonları yaklaşımında ise böyle bir kısıtlamanın olmaması nedeniyle işletmelerin etkinliğinin ölçülmesinde daha üstün bir yöntem olduğu kabul edilmektedir (Lau \& Yotopoulas 1971; Yotopoulas \& Lau 1973; Ali \& Flinn 1989). Kâr fonksiyonları yaklaşımının üretim fonksiyonları yaklaşımından üstünlüğü, bu yöntemde girdi ve çıktı fiyatlarının dışsal olarak modele dahil edilerek işletmecinin girdi kullanımı ile ilgili karar verme sürecinde dikkate almasıdır (Abdulai \& Huffman 1998). Bu nedenle, etkinliğin belirlenmesinde kâr fonksiyonu modellerinin kullanımı daha çok kabul görmektedir. Stokastik kâr sınır yaklaşımı genel olarak aşağıdaki şekilde ifade edilmektedir (Battese \& Coelli 2005):

$$
\pi_{i}=f\left(P_{i j}, Z_{i k}, D_{i j}\right) \exp \left(e_{i}\right)
$$

$\mathrm{Bu}$ eşitlikte $\pi_{i}$, i' inci fïma için toplam gelirden değişken maliyetlerin çıkartılması sonucu elde edilen kârın çıktı fiyatına bölünmesi sonucu elde edilen normalleştirilmiş kârı; $P_{i j}$, i' inci firmanın kullanmış olduğu j'inci girdi fiyatının i'inci firmanın çıktı fiyatına bölümü ile elde edilen normalleştirilmiş girdi fiyatını; $Z_{i k}$; i' inci firmanın sahip olduğu k'ıncı sabit üretim faktörünün seviyesini; $D_{i j}$, işletmeye özgü dişsal değişkenler vektörünü ve $e_{i}$ ise sınır yaklaşımı ile uyumlu olan hata terimini ifade etmektedir.

Kapalı formda Eşitlik 1 ile ifade edilen stokastik kâr modelinin tahmininde uygulamada yaygın olarak standartlaştırılmış Quadratik ve Leontief, Cobb-Douglas ve Translog kâr fonksiyonları kullanılmaktadır. Kâr etkinliğinin saptanmasında kâr fonksiyonu olarak standartlaştırılmış translog olasılıklı kâr sınırı fonksiyonu kullanılmıştır. Bununla birlikte, Translog kâr fonksiyonu diğer kâr fonksiyonlarına göre kâr fonksiyonunun özelliklerini daha iyi yansıtmaktadır. Buna karşın veri setinin hangi fonksiyon kalıbına uygun olduğunun istatistiksel olarak test edilmesi gerekmektedir. Translog fonksiyonun diğer bir avantaj1 ise modeli tahmin ettikten sonra veri setinin Cobb-Douglas mı yoksa Translog kalıba mı uygun olduğunun testine imkan sağlamasıdır. Bu nedenlerle bu çalışmada aşağıda ifade edilen translog fonksiyon kalıbı kullanılmış ve fonksiyon kalıbının seçimine ilişkin test, araştırma bulguları kısmında verilmiştir. Eşitlik 1'de kapalı formda verilen kâr fonksiyonu, translog kâr fonksiyonu formunda aşağıdaki şekilde ifade edilir:

$$
\left.\begin{array}{c}
\ln \Pi=\alpha_{0}+\sum_{i} \alpha_{i} \ln P_{i}+\frac{1}{2} \sum_{i} \sum_{l} \gamma_{i l} \ln P_{i} \ln P_{l}+\sum_{i} \sum_{k} \delta_{i k} \ln P_{i} \ln Z_{k}+ \\
\sum_{k} \beta_{k} \ln Z_{k}+\frac{1}{2} \sum_{k} \sum_{h} \phi_{k h} \ln Z_{k} \ln Z_{h}+V+U
\end{array}\right\}
$$

Bu eşitlikte $\pi$ kârı; $P_{i}$ i'inci girdinin output fiyatı ile standartlaştırılmış fiyatını; $Z_{k}$ k'ıncı sabit faktörün miktarını ve ln doğal logaritmayı ifade etmektedir.
Eşitlik (2)'de $V$ ve $U$ hata terimlerini ifade etmekte olup işletmenin etkin olarak üretim faaliyetinde bulunmaması durumundaki toplam hata payını 
$e=V+U$ göstermektedir. $U$, işletmenin etkin bir şekilde üretim faaliyetinde bulunmaması durumunu ve $V$ ise işletmenin etkin bir şekilde çalışmaması dışındaki hata payı terimlerini ifade etmektedir. Buna göre, $U=0$ ise işletmenin karşılaştığı fiyatlar ve sahip olduğu faktörler ile maksimum kâra ulaştığı durumu açıklamaktadır. Buna karşın, $U>0$ ise işletmenin etkin olmamasından dolayı kâr kaybı olduğunu göstermektedir. $\mathrm{Bu}$ açıklamalara bağlı olarak j'inci işletmenin kâr etkinsizliğine ilişkin indeks (KEI) Eşitlik (2)'den tahmin edilen $U$ 'nun yardımıyla aşağıdaki şekilde hesaplanır:

$$
K E I=\left(1-\exp \left[-u_{j}\right]\right)
$$

İşletmelerin kâr etkinsizliğinin belirlenmesinin yanısıra kâr etkinsizliği üzerine etkili olan işletmeye ait sosyo-ekonomik faktörlerin belirlenmesi de oldukça önemlidir. Bu amaçla, işletmelerin kâr etkinsizliğini etkileyen faktörler aşağıda belirtilen model yardımıyla tahmin edilmiştir:

$$
K E I_{l}=\alpha_{0}+\alpha_{i} E_{i}+\varepsilon_{j}
$$

$\mathrm{Bu}$ eşitlikte $E_{i}$, sosyo-ekonomik değişkenlerden oluşan vektörü; $K E I$ ve $\varepsilon_{j}$ ise sırasıyla işletmenin kâr etkinsizliği ve modelin hata paylarını ifade etmektedir. İncelenen işletmelerde üretim dönemleri itibariyle serada domates üretiminin kâr etkinsizliğinin nedenleri yazlık, güzlük ve kış ekim dönemleri için ayrı ayrı ekonometrik olarak analiz edilmiştir. $\mathrm{Bu}$ amaçla Eşitlik 5 ile ifade edilen translog kâr fonksiyonu her bir dönem için tahmin edilmiştir. Modele dahil edilen değişkenler ve açıklamaları Çizelge 1'de verilmiştir.

$$
\left.\begin{array}{rl}
\ln \pi_{i}=\alpha_{0} & +\alpha_{1} \ln P_{1 i}+\alpha_{2} \ln P_{2 i}+\alpha_{3} \ln P_{3 i}+\alpha_{4} \ln P_{4 i}+1 / 2 \gamma_{11} \ln P_{1 i}^{*} \ln P_{1 i}+1 / 2 \gamma_{22} \ln P_{2 i} * \ln P_{2 i}+1 / 2 \gamma_{33} \ln P_{3 i} * \ln P_{3 i}+1 / 2 \gamma_{44} \ln P_{4 i} * \ln P_{4 i} \\
& +1 / 2 \gamma_{12} \ln P_{1 i} * \ln P_{2 i}+1 / 2 \gamma_{13} \ln P_{1 i} * \ln P_{3 i}+1 / 2 \gamma_{14} \ln P_{1 i} * \ln P_{4 i}+1 / 2 \gamma_{23} \ln P_{2 i} * \ln P_{3 i}+1 / 2 \gamma_{24} \ln P_{2 i} * \ln P_{4 i}+1 / 2 \gamma_{34} \ln P_{3 i} * \ln P_{4 i} \\
& +\delta_{11} \ln P_{1 i} * \ln Z_{1}+\delta_{21} \ln P_{2 i} * \ln Z_{1 i}+\delta_{31} \ln P_{3 i} * \ln Z_{1 i}+\delta_{41} \ln P_{4 i} * \ln Z_{1 i}+\beta \ln Z_{1 i}+1 / 2 \phi_{1} \ln Z_{1 i} * \ln Z_{1 i}+e_{i}
\end{array}\right\}
$$

\begin{tabular}{|c|c|}
\hline \multicolumn{2}{|c|}{ Bă̆ımlı De ğişken } \\
\hline$\pi_{i}$ & $\begin{array}{l}\text { i'inci işletmenin ilgili üretim döneminde serada domates yetiştiriciliğinden elde edilen } \\
\text { normalleştirilmiş brüt kârı }\end{array}$ \\
\hline \multicolumn{2}{|c|}{ Bağımsız Değgişkenler } \\
\hline$P_{1}$ & : İlgili üretim dönemindeki normalleştirilmiş toplam işçilik masrafları, TL \\
\hline$P_{2}$ & : İlgili üretim dönemindeki normalleştirilmiş ilaçlama masrafları, TL \\
\hline$P_{3}$ & : İlgili üretim dönemindeki normalleştirilmiş gübreleme masrafları, TL \\
\hline$P_{4}$ & : İlgili üretim dönemindeki normalleştirilmiş diğer masraflar toplamı, TL \\
\hline$Z_{1}$ & : İşletmenin ilgili üretim dönemindeki domates yetiștiriciliği yaptığı toplam sera alanı, $\mathrm{m}^{2}$ \\
\hline $\mathrm{e}_{1}$ & : Bileşik hata terimi \\
\hline
\end{tabular}

Çizelge 1-Stokastik translog kâr modelinde kullanılan değişkenler ve tanımlamaları

Table 1-The variables used in the stochastic translog profit model and explanations

Her bir dönem için translog kâr fonksiyonları tahmin edildikten sonra, Eşitlik (4) ile ifade edilen kâr etkinsizlik modeli her bir üretim dönemi için tahmin edilmiştir. Kâr etkinsizlik modellerinde yer alan ve KEI ile ifade edilen bağımlı değişken, translog kâr modellerinden elde edilen bileşik hata terimleri kullanılarak Eşitlik (3) yardımıyla hesaplanmıştır. Kâr etkinsizlik modelinde dikkate alınan değişkenler ve açıklamaları Çizelge 2'de verilmiștir. Anket uygulamasıyla elde edilen veriler SPSS 11.0 ve Limdep 9.0 bilgisayar programlarında değerlendirilmiştir.

\section{Bulgular ve Tartışma}

Araştırma kapsamına alınan işletmelerin arazi ve nüfus gibi sosyo-ekonomik özelikleri sera genişlik gruplarına göre incelenmiştir. Buna göre serada domates üretimi yapan üreticilerin yaş ortalaması 42 ve ortalama üreticilik deneyim süresi 15.7 yıldır. Ortalama aile genişliği 3.9 kişi, toplam nüfusun $\% 53.45^{\prime} \mathrm{i}$ erkek ve \%46.55'i ise kadınlardan oluşmaktadır. Anket uygulanan işletmelerde üreticilerin \%66.80'i ilkokul mezunudur. İşletme başına düşen ortalama sera genişliği 4.62 dekar ve 
Çizelge 2-Kâr etkinsizlik modelinde kullanılan değişkenler ve tanımlamaları

Table 2-The variables used in the profit efficiency model and explanations

\begin{tabular}{|c|c|}
\hline \multicolumn{2}{|l|}{ Bağımlı Değişken } \\
\hline KEI & : $i$ 'inci işletmenin kâr etkinsizlik indeksi \\
\hline \multicolumn{2}{|l|}{ Bağımsız Değişkenler } \\
\hline EĞİTìM & : İşletme yöneticisinin eğitim durumu lise ve üstü ise $=1$, değilse $=0$ \\
\hline YAȘ & : İşletme yöneticisinin yaşı \\
\hline SERA TIPİ & : Sera tipi cam ise $=1$, plastik ise $=0$ \\
\hline ARI & : Bombus arısı kullanıyor ise $=1$, kullanmıyor ise $=0$ \\
\hline HAVALANDIRMA & : Havalandırma alanı ortalamanın üstünde ise $=1$, altında ise $=0$ \\
\hline TOPRAK & : Toprak analizi yaptırıyor ise $=1$, yaptırmıyor ise $=0$ \\
\hline FIDE & : Asılı fide kullanıyor ise $=1$, asili fide kullanmiyor ise $=0$ \\
\hline
\end{tabular}

ortalama sera sayıs1 2.72 'dir. İşletmelerin \%93.19'u mülk, \%2.62'sini kiraya tutulan arazi ve \%4.19'unu ortakçılıkla işletilen arazilerden oluşmaktadır. İncelenen işletmelerde sera varlığının \%38.3'ü cam sera, \%61.7'si ise plastik seradır. Cam seraların $\% 60.98$ 'i tek, \%20.08'i blok ve \%18.94'ü bitişik seradır. Plastik seraların ise \%37.29'u blok, \%33.90'1 tek ve \%28.81'i bitişiktir. İşletmelerdeki cam seraların kullanım süreleri incelendiğinde işletmelerin \%58.71'inin 10-20 yıl, \%24.62'sinin 110 y1l arasinda ve $\% 16.67$ 'sinin ise 20 yil ve üzerinde kullanım süresine sahip seraya sahip oldukları belirlenmiştir. Plastik seralarda ise kullanım süresi açısından 1-10 yıllık olan seralar \%49.13 ile ilk sirada yer almaktadır. Bunu \%45.95 ile 10-20 yıl arasında ve \%4.91 ile 20 ve üzeri yıllık olan seralar izlemektedir.

Araştırma kapsamındaki 256 üreticinin \%80.86'sinin domates üretiminde bombus arıs1 kullandıkları anlaşılmıştır. Arı kullanımı genel olarak çift ekim döneminde daha fazladır. Güzlük dönemde arı kullanımı \%84.31, yazlık dönemde \%81.16, kışlık ekimde ise \%76.47'dir. Görüşme yapılan üreticilerin \%50.39'unun Ziraat Odasına ve Tarım Kredi Kooperatifine üye olduğu Üretici Birliklerine üyeliğin ise çok sınırlı olduğu saptanmıştır. İncelenen işletmelerde üreticilerin \%82.42'si gibi önemli bir kısmı tarımsal sigorta yaptırmamaktadır. Tarım sigortası yaptıran işletmelerin \%55.56'sı dolu sigortas1, \%44.44'ü firtına ve dolu sigortası yaptırmaktadır. Tarım sigortası yaptırmayan üreticilerin, sigortayı tercih etmeme nedenleri içinde en belirgin olanı sigorta primini yüksek bulmalarıdır. Araştırma kapsamındaki üreticilerin \%56.64'ü sera alanını genişletmeyi ve \%52.73'ü modern seracılik yapmayı düşünmektedir.

Görüşme yapılan üreticilerin \%50.39'u toprak analizi yaptırmakta ve ancak \%10.16's1 organik domates üretimine olumlu bakmaktadır. Diğer yandan incelenen işletmelerde üreticilerin ancak \%18.36's1 Eurepgap yaklaşımına göre üretim yaptıklarını belirtmişlerdir. Üreticilerin domates üretimindeki bilgi kaynakları arasında \%86.33 ile ilaç bayii temel kaynaktır. Araştırma bölgesinde son yıllarda uygulama alanı bulmaya başlayan özel danışmanlık sisteminin henüz yaygınlık kazanmadığ1 ve üreticilerin sadece \%8.98'inin danışmanlık hizmeti aldığı belirlenmiştir. Domates üretiminde incelenen işletmelerin \%54.49'u ekonomik, \%45.51'i teknik sorunlarla karşılaştıklarını belirtmişlerdir. Araştırma sonuçlarına göre üreticilerin \%69.32'si ürünlerini pazarladıkları hal sisteminin işleyişinden memnun olmadıklarını belirtmişlerdir.

Çift ekim domates üretimi yapan işletmelerde dekara toplam domates üretim değeri 15,200.47 TL olup, güzlük üretim değeri toplam değerin \%51.8'ine, yazlık domates üretim değeri toplam değerin \%48.2'sine karşllık gelmektedir. Tek ekim domates üretimi yapan işletmelerde dekar başına ortalama domates üretim değeri 12,104.27 TL'dir. Üretim dönemleri ayrı ayrı değerlendirildiğinde 256 işletme başına dekara üretim değeri ortalama 9,131.80 TL olarak bulunmuştur.

İşletmeler ortalamasında üretim masraf1 7,398.20 TL da ${ }^{-1}$ dır. Bu değerin \%48.17'si değişken, \%51.83'ü sabit masraflardır. Kışlık, güzlük ve yazlık domates üretimi yapan işletmelerde dekara üretim masrafları sırasıyla 9,061.98 TL, 6,843.63 TL ve 6,168.41 TL olarak hesaplanmıştır. Cam serada domates üretim 
verilerinin elde edildiği 93 işletmenin ortalamasına bakıldığında değişken masrafların, toplam masrafların \%46.29'unu oluşturduğu (3,656.71 TL) buna karşın sabit masrafların \%53.71 (4,243.58 TL) olduğu görülmektedir. Plastik serada üretilen domatesin dekara ortalama maliyetlerinin \%49.36's1 (3,510.19 TL) değişken, \%50.64'ü ise $(3,601.53 \mathrm{TL})$ sabit masraflardan oluşmaktadır.

İşletmeler ortalaması olarak birim alana (dekar) net kâr ve brüt kâr sirasiyla 1,733.59 TL ve 5,568.37 TL' dir. Çift ekim domates üretiminde brüt kâr 8,993.65 TL ile tek ekime (7,773.69 TL) göre daha yüksektir. Sera tiplerine göre değerlendirildiğinde ise cam seralarda en yüksek brüt kâr $(9,484.93$ TL) ve net kâr $(4,442.80$ TL) kışlık üretimden, plastik seralarda en yüksek brüt $(4,507.07$ TL) ve net kâr $(1,266.36$ TL) yazlık üretimden elde edilmiştir. Cam sera ile plastik seranın brüt ve net kârlılığı hesaplandığında ise cam seranın plastik seradan daha kârlı olduğu ortaya çıkmıştır. Cam seralarda kışlık, güzlük ve yazlık üretim yapan işletmelerde dekara toplam gelir sirasiyla 14,273.65 TL, 8,782.26 TL ve 9,242.49 TL'dir. İncelenen işletmelerde üreticiler cam serada kışlık domates ekiminden kilogram başına $0.31 \mathrm{TL}$ ile güzlük (0.08 TL) ve yazlık $(0.11 \mathrm{TL})$ domates ekiminden daha fazla kâr elde etmektedir. Üreticiler plastik serada ise kışlık ekiminden kilogram başına 0.14 TL ile güzlük $(0.12 \mathrm{TL})$ ve yazlık $(0.12 \mathrm{TL})$ ekimden daha fazla kâr elde etmektedir.

Her üç üretim dönemi için fonksiyon kalıbı seçiminde $L R$ (Olabilirlilik Oranı) testi kullanılmış olup \%1 önem düzeyinde $(P=0.01)$ veri setinin Cobb-Douglas fonksiyon kalıbına uygun olduğunu öngören sıfır hipotezi reddedilmiştir. Veri setine uygun fonksiyon kalıbının translog olduğunu belirten alternatif hipoteze uygun olarak tahmin edilen modellerin tahmin sonuçları Çizelge 3'te verilmiştir.

Model tahmin sonuçlarına göre, her üç üretim dönemi için hesaplanan $\lambda$ değerleri $\% 1$ önem seviyesinde önemli bulunmuş olup etkinsizliği ifade eden hata teriminin $(u)$, rassal hata terimine $(v)$ baskın olduğunu göstermektedir. Güzlük, yazlık ve kışlık domates üretimi yapan işletmelerin elde ettikleri kârların ulaşabilecekleri maksimum kârdan daha düşük olmasının nedeni, işletme dışındaki tesadüfi faktörlerden değil, işletmeler arasındaki uygulama farklılığından kaynaklandığını göstermektedir.

Güzlük ekim yapan tüm işletmeler için ortalama kâr etkinsizlik değeri 0.16 olup bu değerin 0.04 ile 0.58 arasında değiştiği hesaplanmıştır. $\mathrm{Bu}$ sonuca göre, teknik ve dağılım etkinsizliğinden dolayı işletmeler ortalama olarak ulaşabilecekleri kârdan \%15.8 kadar daha az kârla üretim yapmaktadırlar. Ayrıca, kâr etkinsizlik değerlerinin dağılımı incelendiğinde işletmelerin \%70'inin ortalama kâr etkinsizlik değerinden daha düşük bir değere sahip oldukları belirlenmiştir. Model tahmin sonuçları kullanılarak etkinsizlikten dolayı güzlük ekim yapan işletmelerde ortalama dekara kâr kaybının 578.92 TL olduğu hesaplanmıştır.

Modelin iktisadi olarak değerlendirmede büyük önem arz eden değişkenler açısından model sonuçlarına göre; işçilik, ilaçlama, gübreleme ve diğer toplam masraflardaki artışın kâr üzerinde olumlu etki yarattığ 1 belirlenmiştir. İstatistiki açıdan, bu değişkenlerden yalnızca gübreleme ve diğer toplam masraflar önemli bulunmuştur. Buna göre güzlük ekim yapan işletmelerde, ortalama kâr etkinsizliğinin \%15.8 olduğu dikkate alınırsa üretimde girdi masraflarında meydana gelecek artış toplam gelirde daha fazla bir artış sağlayarak işletmelerin kârlılığında artışa neden olacaktır.

İncelenen dönemde serada yazlık ekim yapan tüm işletmeler için ortalama kâr etkinsizlik değeri 0.21 olarak hesaplanmıştır. Bu sonuca göre, yazlık domates üretiminde teknik ve dağılım etkinsizliğinden dolayı işletmeler ortalama olarak ulaşabilecekleri kârdan \%21 kadar daha az kârla üretim yapmaktadırlar. İşletmelerin \%65'inin ortalama kâr etkinsizlik değerinden daha düşük bir değere sahip oldukları belirlenmiştir. Ayrıca, etkinsizlikten dolayı yazlık domates üretimi yapan işletmelerde ortalama dekara kâr kaybı 926.3 TL'dir.

Kışlık ekim yapan işletmeler için ortalama kâr etkinsizlik değeri 0.17 olarak hesaplanmıştır. Model tahmin sonucuna göre, teknik ve dağılım etkinsizliğinden dolayı işletmeler ortalama olarak ulaşabilecekleri kârdan \%16.91 kadar daha az kârla üretim yaptıkları sonucuna ulaşılmıştır. Kâr etkinsizlik değerlerinin dağılımı incelendiğinde 
Çizelge 3-Güzlük, yazlık ve kışlık ekimde stokastik translog kâr modeli tahmin sonuçları

Table 3-Maximum likelihood estimates of the stochastic profit frontier function for fall, winter and spring periods

\begin{tabular}{|c|c|c|c|c|c|c|c|c|c|}
\hline & \multicolumn{3}{|c|}{ Güzlük } & \multicolumn{3}{|c|}{ Klşlık } & \multicolumn{3}{|c|}{ Yazlık } \\
\hline & Parametre & t-Değeri & $P$ değeri & Parametre & t-Değgeri & $P$ değeri & Parametre & t-Değgeri & $P$ değeri \\
\hline Sabit & -3.714 & -0.686 & 0.4929 & -5.262 & -3.38 & 0.118 & 3.767 & 1.562 & 0.00 \\
\hline $\ln P_{2}$ & 1.244 & 0.450 & 0.6527 & 0.997 & 3.54 & 0.229 & -0.914 & -1.203 & 0.00 \\
\hline $\ln P_{3}$ & 5.560 & 1.751 & 0.0800 & 2.827 & 7.99 & 0.002 & 2.681 & 3.090 & 0.00 \\
\hline $\ln P_{4}$ & 4.569 & 1.623 & 0.1045 & 1.370 & 3.51 & 0.002 & -3.663 & -3.094 & 0.00 \\
\hline $1 / 2 \ln P_{1} \times \ln P_{1}$ & -0.477 & -0.996 & 0.3192 & 0.475 & 5.90 & 0.853 & 0.057 & 0.185 & 0.00 \\
\hline $1 / 2 \ln P_{2} \times \ln P_{2}$ & -0.751 & -1.071 & 0.2843 & -1.297 & -8.39 & 0.135 & -0.475 & -1.496 & 0.00 \\
\hline $1 / 2 \ln P_{3} \times \ln P_{3}$ & -0.072 & -0.090 & 0.9286 & -4.124 & -30.15 & 0.422 & -0.545 & -0.803 & 0.00 \\
\hline $1 / 2 \ln P_{4} \times \ln P_{4}$ & -0.836 & -0.701 & 0.4835 & -1.431 & -7.05 & 0.068 & 0.863 & 1.823 & 0.00 \\
\hline $1 / 2 \ln P_{1} \times \ln P_{2}$ & -1.227 & -1.720 & 0.0854 & 0.337 & 3.19 & 0.425 & 0.327 & 0.797 & 0.00 \\
\hline $1 / 2 \ln P_{3} \times \ln P_{4}$ & 0.503 & 0.284 & 0.7763 & -0.939 & -5.25 & 0.000 & -4.029 & -4.317 & 0.00 \\
\hline $\ln P_{1} \times \ln Z_{1}$ & -1.445 & -1.147 & 0.2514 & 1.615 & 12.67 & 0.918 & 0.064 & 0.103 & 0.00 \\
\hline $\ln P_{2} \times \ln Z_{1}$ & 1.629 & 1.133 & 0.2574 & 0.535 & 2.51 & 0.005 & -1.716 & -2.814 & 0.01 \\
\hline $\ln P_{3} \times \ln Z_{1}$ & -2.732 & -1.524 & 0.1276 & 5.218 & 22.88 & 0.166 & 1.483 & 1.385 & 0.00 \\
\hline $\ln P_{4} \times \ln Z_{1}$ & -1.424 & -0.527 & 0.5983 & 2.270 & 9.83 & 0.390 & 0.965 & 0.860 & 0.00 \\
\hline $1 / 2 \ln Z_{1} \times \ln Z_{1}$ & 6.207 & 1.242 & 0.2141 & -8.976 & -13.85 & 0.928 & -0.220 & -0.090 & 0.00 \\
\hline$\lambda$ & 5.581 & 1.761 & 0.0015 & 7.537 & 6.697 & 0.0009 & 5.332 & 6.001 & 0.00 \\
\hline
\end{tabular}

işletmelerin \%58'inin ortalama kâr etkinsizlik değerinden daha düşük bir değere sahip oldukları belirlenmiştir.

Model tahmin sonuçları kullanılarak etkinsizlikten dolayı kışlık ekim yapan işletmelerde ortalama dekara kâr kaybının 1,100.12 TL olduğu hesaplanmıştır. İstatistiksel olarak bu değişkenlerden yalnızca gübreleme ve diğer toplam masraflar önemli bulunmuştur $(P \leq 0.01)$. İncelenen işletmelerde, ortalama kâr etkinsizliğinin \%16.91 olduğu dikkate alınırsa üretim girdisi masraflarında meydana gelecek artış toplam gelirde daha fazla bir artış sağlayacak, bu artış da işletmelerin kârlılık düzeyinin yükselmesini sağlayacaktır.

Serada güzlük, yazlık ve kışlık domates üretimi yapan işletmelerde kâr etkinsizliğinin nedenlerini açıklayan model, Genelleştirilmiş En Küçük Kareler Yöntemi ile tahmin edilmiş ve modelin tahmin sonuçları Çizelge 4'te verilmiştir. Tahmin edilen model parametrelerinin önemli bir kısmı iktisadi beklentiye uygundur. Güzlük ekim için modele dahil edilen değişkenlerden işletme yöneticisinin yaşının ortalama yaşın üzerinde olması durumunda kâr etkinsizliği azalmaktadır. Diğer bir ifadeyle, işletme yöneticisinin yaşının artması aynı zamanda seracılık deneyiminin de artması şeklinde yorumlanabileceğinden dolayı bu sonuç beklentiye uygundur. Benzer şekilde, güzlük ekim yapan işletme yöneticisinin eğitim düzeyi ile kâr etkinsizliği arasında yine ters yönlü bir ilişki bulunmaktadır. İşletme yöneticisinin almış olduğu formal eğitim arttıkça işletmecinin yeniliklere açık olması ve dolayısıyla daha bilinçli bir üretim faaliyetinde bulunması nedeniyle bu işletmelerin kâr etkinsizliği daha düşük bulunmuştur.

İşletmenin sahip olduğu seranın teknik özelliklerini yansıtması açısından ve verim üzerinde önemli etkileri olan seranın havalandırma alanı modele dahil edilmiştir. Tahmin sonuçlarına göre seranın havalandırma alanı arttıkça beklentiye uygun olarak etkinsizlik azalmaktadır. Sera tesis aşamasında havalandırma alanlarının teknik koşullara uygun olarak yer verilmesi önem arz etmektedir. $\mathrm{Bu}$ konuda üreticilerin yayım faaliyetleri ile bilinçlendirilmesi, işletmelerin etkinliklerinin artmasında katkı sağlayacaktır. 
Çizelge 4-Güzlük, yazlık ve kışlık ekimde kâr etkinsizliği modeli tahmin sonuçları

Table 4-Results of profit inefficiency model for fall,winter and spring periods

\begin{tabular}{|c|c|c|c|c|c|c|c|c|c|}
\hline \multirow[b]{2}{*}{ DEĞİŞKEN } & \multicolumn{3}{|c|}{ Güzlük } & \multicolumn{3}{|c|}{ Kışlık } & \multicolumn{3}{|c|}{ Yazlık } \\
\hline & Parametre & t-Değeri & $P$ değeri & Parametre & t-Değeri & $P$ değeri & Parametre & t-Değeri & $P$ değeri \\
\hline Sabit & 0.319 & 3.99 & 0.00 & 0.135 & 1.96 & 0.06 & 0.368 & 2.02 & 0.05 \\
\hline YAŞ & -0.003 & -2.20 & 0.08 & 0.004 & 2.97 & 0.30 & 0.004 & 1.18 & 0.63 \\
\hline EĞİTİM & -0.047 & -1.77 & 0.03 & -0.026 & -1.05 & 0.01 & -0.023 & -0.48 & 0.24 \\
\hline SERA TIPİ & 0.014 & 0.56 & 0.58 & -0.019 & -0.75 & 0.46 & -0.088 & -1.46 & 0.15 \\
\hline ARI & -0.020 & -0.57 & 0.57 & 0.007 & 0.2 & 0.85 & -0.173 & -2.29 & 0.03 \\
\hline HAVALANDIRMA & -0.039 & -1.67 & 0.10 & 0.018 & 0.75 & 0.46 & -0.116 & -1.79 & 0.08 \\
\hline TOPRAK & -0.038 & -1.70 & 0.09 & -0.058 & -1.94 & 0.06 & 0.003 & 0.05 & 0.96 \\
\hline FIDE & 0.118 & 1.62 & 0.11 & -0.015 & -0.46 & 0.64 & 0.312 & 6.09 & 0.00 \\
\hline
\end{tabular}

Tahmin sonucuna göre işletmecinin toprak analizi yaptırması etkinsizliği azaltan önemli bir faktördür. İşletmecinin toprak analizi yaptırması sonucunda toprağın ihtiyaç duyduğu bitki besin elementlerinin ve bu elementlerin kullanım düzeyi belirleneceği için uygulama üretim üzerinde olumlu etkide bulunarak kâr etkinliğinin artmasına neden olmaktadır. Model sonuçlarına göre, güzlük ekimde bombus arısı kullanan işletmelerin kâr etkinsizliklerinin daha düşük olduğu belirlenmiş olmasına karşın bu değişkene ait etki istatistiksel olarak önemli bulunmamıştır. Modelde yer verilen diğer bir değişken ise işletmenin sahip olduğu sera tipidir. Güzlük ekimde plastik serada üretim yapan işletmelerin cam serada üretim yapanlara göre kâr açısından daha etkin olduğu sonucuna ulaşılmış olmasına karşın bu etki de istatistiksel olarak önemli bulunmamıştır. İşletmenin aşılı fide kullanmasının teorik olarak etkinsizliği azaltması beklenirken, model sonuçlarına göre istatistiksel olarak kâr etkinsizliği üzerinde etkili olmadığı belirlenmiştir. Bunun en önemli nedeni olarak işletmelerde güzlük ekimde aşılı fide kullanımının yaygın olmamasidır.

Kışlık ekim için tahmin edilen model sonuçlarına göre modele dahil edilen değişkenlerden işletmecinin toprak analizi yaptırmasının beklentiyle uyumlu olarak işletmenin kâr etkinsizliğini azaltıcı yönde etkide bulunduğu belirlenmiştir. İşletmecinin toprak analizi yaptırması ile toprağın ihtiyaç duyduğu bitki besin elementlerinin belirlenmesi ve söz konusu eksik bitki besin elementlerinin karşılanması üretim üzerinde olumlu etkide bulunarak kâr etkinliğinin artmasına neden olmaktadır. Kışlık ekim için kâr etkinsizlik modeline dahil edilen bir diğer değişken ise işletme yöneticisinin yaşıdır. İşletme yöneticisi yaşının etkisi pozitif ve istatistiksel olarak önemli bulunmuş olup; işletme yöneticisinin yaşı arttıkça etkinsizliğin azaldığını ifade etmektedir. Model tahmin sonucunda, kışlık ekim yapan işletmelerde işletme yöneticisinin eğitim düzeyi ile kâr etkinsizliği arasında ters yönlü bir ilişki olduğu belirlenmiştir. Kışlık ekim için kâr etkinsizlik modeline dahil edilen seranın havalandırma alanı ile işletmede bombus arısının kullanılıp kullanılmaması istatistiksel olarak önemsiz ve ilgili değişkenlerin katsayısı pozitif olarak tahmin edilmiştir.

Analiz sonuçlarına göre, yazlık ekimde seranın havalandırma alanı ile bombus arısı kullanımı işletmenin kâr etkinsizliğini istatistiki olarak önemli derecede azaltan değişkenlerdir. Bununla birlikte, işletmecinin eğitim seviyesi ve sera tipi güz dönemi model tahmin sonuçlarıyla benzerlik göstermesine karşın istatistiksel olarak önemli bulunmamıştır $(P \geq 0.05)$.

\section{Sonuçlar}

Antalya ilinde işletmelerin sosyo-ekonomik özelikleri dikkate alınarak, olasılıklı kâr sınırı yaklaşımı ile işletmelerin kâr etkinliği analizinin yapıldığı çalışmada model tahmin sonuçları, değişkenlerin önemli bir kısmının beklenti ile uyumlu olduğunu ve ekinsizlik hata teriminin rassal hata teriminden baskın olduğunu göstermiştir. $\mathrm{Bu}$ 
sonuca göre, işletmelerin ulaşabilecekleri kâr düzeyinden daha düşük kâr elde etmesinin temel nedenleri işletmelerin kaynaklarını etkin bir şekilde dağıtmaması ve kullanmaması olarak belirtilebilir. Güzlük dönemde üretim yapan işletmelerin \%65'inin, yazlık dönemde üretim yapan işletmelerin \%70'inin ve kışlik dönemde \%58'inin üretim dönemine göre ortalama kâr etkinsizlik değerinden daha düşük bir değere sahip oldukları belirlenmiştir. Kâr değerinin kâr sınırından farkının en az olduğu üretim dönemi olan kışlık dönemde, kaynak dağılım etkinliği ve teknik etkinlik sağlanması durumunda elde edilecek kâr kazancı en yüksek, bu farkın en yüksek olduğu güzlük dönemde ise en düşüktür.

\section{Teşekkür}

Bu araştırma, TÜBİTAK (TOVAG 106 O 026) tarafından desteklenmiştir.

\section{Kaynaklar}

Abdulai A \& Huffman W E (1998). An Examination of Profit Efficiency of Rice Farmers in Northern Ghana. Staff Paper, Swiss Federal Institute of Technology, Department of Agricultural Economics, 27

Ali M \& Flinn J C (1989). Profit efficiency among basmati rice producers in Pakistan Punjab. American Journal of Agricultural Economics 71: 303-310

TKB (2005). Tarım ve Köyişleri Bakanlığı, Antalya İl Master Planı

TKB (2006). Tarım ve Köyişleri Bakanlığı Antalya Tarım İl Müdürlüğü Çalışma Raporları

Battese G E \& Coelli T J (2005). A model for technical inefficiency effects in a stochastic frontier production function for panel data. Emprical Economics 20(2): 325-332

Lau L J\& Yotopoulos P A (1971). A test for relative efficiency and aplications to Indian Agriculture. American Economic Review 61: 94-109

Özkan B, Akçaöz H V \& Karadeniz C F (2001). Antalya ilinde serada sebze üretimine yer veren işletmelerin ekonomik analizi. Bahçe Dergisi 30(1-2): 109-115

Özkan B (2003). Antalya ilinde serada tek ve çift ekim domates üretiminin ekonomik analizi. Akdeniz Üniversitesi Bilimsel Araştırma Projeleri Yönetim Birimi, Proje No:21.01.0104.13, Antalya
TÜİK (2006).Türkiye İstatistik Yıllığı, T.C. Türkiye İstatistik Kurumu, Ankara

Yamane T (2001). Temel Örnekleme Yöntemleri (Çev: A Esin, C Aydın, MA Bakır \& Gürbüzsel E). Literatür Yayınları, No: 53, İstanbul

Yotopoulos P A\& Lau L J (1973). A test for relative economic efficiency: some further results. The American Economic Review 63: 214-23 